\title{
BMJ Open Healthy Ageing and Intellectual Disability study: summary of findings and the protocol for the 10-year follow- up study
}

\author{
Marleen J de Leeuw (D) , ${ }^{1}$ Alyt Oppewal (D) , ${ }^{1}$ Roy G Elbers (D) , ${ }^{1}$ \\ Mireille W E J Knulst, ${ }^{1}$ Marco C van Maurik (D) , ${ }^{1}$ Marjoleine C van Bruggen (D) , ${ }^{1}$ \\ Thessa I M Hilgenkamp (D) , ${ }^{1,2}$ Patrick J E Bindels (D) , 3 \\ Dederieke A M Maes-Festen (iD) ${ }^{1}$
}

To cite: de Leeuw MJ, Oppewal A, Elbers RG, et al. Healthy Ageing and Intellectual Disability study: summary of findings and the protocol for the 10-year follow-up study. BMJ Open 2022;12:e053499. doi:10.1136/ bmjopen-2021-053499

- Prepublication history and additional supplemental material for this paper are available online. To view these files, please visit the journal online (http://dx.doi.org/10.1136/ bmjopen-2021-053499).

Received 17 May 2021 Accepted 07 January 2022

D) Check for updates

(c) Author(s) (or their employer(s)) 2022. Re-use permitted under CC BY-NC. No commercial re-use. See rights and permissions. Published by BMJ.

${ }^{1}$ Department of General Practice, Intellectual Disability Medicine, Erasmus MC, University Medical Center, Rotterdam, Netherlands ${ }^{2}$ Department of Physical Therapy, University of Nevada, Las Vegas, Las Vegas, Nevada, USA

${ }^{3}$ Department of General Practice, Erasmus MC, University Medical Center, Rotterdam, Netherlands

Correspondence to

Marleen J de Leeuw;

m.j.deleeuw@erasmusmc.nl

\section{ABSTRACT}

Introduction The Healthy Ageing and Intellectual Disability (HA-ID) study is a prospective multicentre cohort study in the Netherlands that started in 2008, including 1050 older adults (aged $\geq 50$ ) with intellectual disabilities (ID). The study is designed to learn more about the health and health risks of this group as they age. Compared with the amount of research in the general population, epidemiological research into the health of older adults with ID is still in its infancy. Longitudinal data about the health of this vulnerable and relatively unhealthy group are needed so that policy and care can be prioritised and for guiding clinical decision making about screening, prevention and treatment to improve healthy ageing. Methods and analysis This article presents a summary of the previous findings of the HA-ID study and describes the design of the 10-year follow-up in which a wide range of health data will be collected within five research themes: (1) cardiovascular disease; (2) physical activity, fitness and musculoskeletal disorders; (3) psychological problems and psychiatric disorders; (4) nutrition and nutritional state; and (5) frailty.

Ethics and dissemination Ethical approval for the 10year follow-up measurements of the HA-ID study has been obtained from the Medical Ethics Review Committee of the Erasmus MC, University Medical Centre Rotterdam (MEC2019-0562).

Trial registration number This cohort study is registered in the Dutch Trial Register (NTR number NL8564) and has been conducted according to the principles of the Declaration of Helsinki.

\section{INTRODUCTION}

The Healthy Ageing and Intellectual Disability (HA-ID) study is a prospective multicentre cohort study including older adults with intellectual disabilities (ID) in the Netherlands. The study was designed in response to the increasing longevity of people with ID and the lack of epidemiological data about their health and health risks at older ages. The absence of this knowledge raised questions

\section{Strengths and limitations of this study}

- This protocol outlines the design of the 10-year follow-up of the Healthy Ageing and Intellectual Disability (HA-ID) study, a prospective multicentre cohort study in which a heterogeneous group of 1050 older adults with intellectual disabilities (ID) is followed over time.

- The longitudinal design of the study makes it possible to make statements about causality and to study health progress and health indicators, which is important for prioritising policy and care and guiding clinical decision making about screening, prevention and treatment to improve healthy ageing.

- The comprehensive set of measurements makes it possible to evaluate the health of older adults with ID from a broad perspective and to investigate the interrelationships between medical domains.

- The data collection consists of measurements that have been shown to be feasible, valid and reliable in older adults with ID, based on previously acquired knowledge and experience within the HA-ID study.

- For financial and feasibility reasons, it has not been possible to perform follow-up measurements on a more regular basis.

about how to organise care and support for this vulnerable and relatively unhealthy group. ${ }^{1}$ Based on this need for knowledge, a consortium was established in 2006 consisting of three ID care organisations (Ipse de Bruggen, Amarant and Abrona) and the research group of Intellectual Disability Medicine of the Erasmus MC, University Medical Centre Rotterdam. The HA-ID consortium aims to (1) increase knowledge on healthy ageing in people with ID through scientific research; (2) strengthen the scientific attitude of care professionals through participation in research and continuous education; and (3) innovate care by implementing research 
outcomes. In 2008, the HA-ID study started with a focus on physical activity and fitness, nutrition and nutritional state and mood and anxiety. A detailed description of the rationale and design of the baseline measurements can be found elsewhere. ${ }^{1}$ After 3 and 5 years, follow-up measurements consisting of medical file research and questionnaires about the health of the participants were completed. New topics were included during this follow-up period: cardiovascular disease (CVD), frailty, mortality and causes of death. ${ }^{2}$

The baseline results of the HA-ID study showed that older adults with ID had more health problems than their peers in the general population and that these problems occurred at younger ages. ${ }^{34}$ Older adults with ID became frail earlier and became more severely frail than their peers in the general population. ${ }^{5}$ High prevalences of polypharmacy, ${ }^{6}$ multimorbidity, ${ }^{6}$ sleep problems, ${ }^{7}$ major depressive disorders, ${ }^{8}$ dysphagia, ${ }^{9}$ obesity, ${ }^{10}$ suboptimal nutritional intake ${ }^{11}$ and low physical activity and fitness levels were found. ${ }^{12-15}$

Based on data from the 3-year and 5-year follow-ups, frailty at baseline was predictive for the development of comorbidity, ${ }^{16}$ a decline in daily functioning and mobility ${ }^{17}$ increased medication use, ${ }^{16}$ increased care intensity ${ }^{18}$ and a higher mortality risk. ${ }^{19}$ Also poor physical fitness was predictive for a decline in mobility, ${ }^{20}$ daily functioning ${ }^{20}{ }^{21}$ and for a higher mortality risk. ${ }^{22}$ Use of atypical antipsychotics, chronic kidney disease, abdominal obesity and histories of stroke and heart failure were predictive for developing CVD over a 3-year period. ${ }^{23}$ These first results from the longitudinal data of the HA-ID study provided important insights for policy and care about how to contribute to a better health of older adults with ID. The results of the HA-ID study have been used in developing diagnostic instruments and guidelines ${ }^{324} 25$ and to illustrate the vulnerability and poor health situation of people with ID, resulting in changes to the Dutch legislation on long-term financing of support, care and treatment for people with ID.

Following the start of the HA-ID study, other research groups initiated longitudinal studies focusing on various aspects of health in adults with ID, such as the IDS-TILDA study in Ireland, ${ }^{26}$ the SAge-ID study in Australia ${ }^{27}$ and a longitudinal cohort study about dementia and mortality in people with Down syndrome in the Netherlands. ${ }^{28}$ Despite these initiatives, epidemiological research into the health of adults with ID is still extremely limited. Too little is known about the health of this group as they age, or about changes in health status over time and early indicators for health problems. However, this knowledge is important for providing the evidence base for improving care and support of older adults with ID and guiding care providers in preparing for this growing group of elderly with ID. Longitudinal research makes it possible to make statements about causality, which contributes to for example, identifying group-specific risk factors, groups at risk of specific diseases and other negative outcomes such as declining in independence. This knowledge can be used to reduce the occurrence of specific risk factors and identify, monitor and treating high-risk groups in good time. More longitudinal studies focusing on the health of this specific group are therefore urgently needed.

This article describes the design for the 10-year follow-up measurements of the HA-ID cohort. To learn more about changes in health status and indicators for health problems over time, a wide range of health data will be collected. Based on previous measurements and results, the focus will be on five research themes: (1) cardiovascular disease; (2) physical activity, fitness and musculoskeletal disorders; (3) psychological problems and psychiatric disorders (including sleep problems); (4) nutrition and nutritional state (including dysphagia); and (5) frailty. This article presents the design of the HA-ID cohort study and a summary of the main findings up to now, and provides an update of the planned measurements of the 10-year follow-up research themes.

\section{METHODS AND ANALYSIS \\ Study cohort}

The HA-ID cohort consists of older adults with borderline to profound ID. All participants receive care or support from one of the care organisations of the HA-ID consortium. These organisations provide care to a wide spectrum of individuals with ID (in terms of the level of ID, residential status and mobility) in various settings (central residential settings, community-based homes, day activity centres and supported living) in both urban and rural areas in various regions in the Netherlands. At baseline, the care organisations provided care to approximately $10 \%$ of the total Dutch ID population receiving care or support from an ID care organisation. ${ }^{29}$ At the start of the study, $10 \%$ of the individuals receiving care from the HA-ID care organisations was 50 or older, comparable to the total Dutch ID population receiving care or support from ID care organisations. ${ }^{29}$ Based on these numbers, we concluded that the base population was representative for the total population of older adults with ID receiving care or support from ID care organisations in the Netherlands. ${ }^{1}$ All individuals with ID within the consortium aged 50 or older by September 2008 were eligible to participate and received an invitation. Ultimately, 1050 of the $2322(45.2 \%)$ invited individuals with ID participated in the baseline measurements. Table 1 presents the baseline characteristics of the participants, which were largely comparable to the overall group of invited individuals with ID and formed a near-representative study population for the total Dutch population of older adults with ID receiving formal support or care, with an under-representation of 80 to 84 year olds, a slight overrepresentation of women and an under-representation of the more independent group. A more detailed description of the representativeness of the sample has been published elsewhere. ${ }^{1}$

Figure 1 summarises the number of participants in the cohort over time. At baseline, measurements consisted 


\begin{tabular}{lc}
$\begin{array}{l}\text { Table } 1 \text { Baseline characteristics of the HA-ID cohort } \\
(\mathrm{n}=1050)^{1}\end{array}$ & $\mathbf{n}(\%)$ \\
\hline Characteristic & $539(51.3)$ \\
\hline Sex & $511(48.7)$ \\
\hline Male & $60(11,50-93)^{\star}$ \\
\hline Female & \\
\hline Age & $31(3.0)$ \\
Level of ID & $223(21.2)$ \\
\hline Borderline & $506(48.2)$ \\
\hline Mild & $172(16.4)$ \\
\hline Moderate & $91(8.7)$ \\
Severe & $27(2.6)$ \\
\hline Profound &
\end{tabular}

Residential status

$\begin{array}{lr}\text { Central setting } & 557(53.0) \\ \text { Community based } & 432(41.1) \\ \text { Independent with ambulatory support } & 43(4.1) \\ \text { With relatives } & 7(0.7) \\ \text { Unknown } & 11(1.1)\end{array}$

Level of care (ZZP-scores)

\begin{tabular}{lr} 
Only day care indication & $6(0.6)$ \\
Only indication ambulant care & $37(3.5)$ \\
Residence with minimal support (1 VG) & $12(1.1)$ \\
$\begin{array}{l}\text { Residence with support (2 VG) } \\
\text { Residence with support and care (3 VG) }\end{array}$ & $138(13.7)$ \\
$\begin{array}{l}\text { Residence with support and intensive } \\
\text { care (4 VG) }\end{array}$ & $207(19.7)$ \\
$\begin{array}{l}\text { Residence with intensive support and } \\
\text { intensive care (5 VG) }\end{array}$ & $325(31.0)$ \\
$\begin{array}{l}\text { Residence with intensive support, care } \\
\text { and regulation of behaviour (6 VG) } \\
\text { (Enclosed) residence with very intensive }\end{array}$ & $93(8.9)$ \\
$\begin{array}{l}\text { support, care and regulation of } \\
\text { behaviour (7 VG) }\end{array}$ & \\
$\begin{array}{l}\text { Mental Healthcare ZZP scores } \\
\text { Unknown }\end{array}$ & $49(4.7)$ \\
\hline
\end{tabular}

${ }^{*}$ Median (IQR, range).

HA-ID, Healthy Ageing and Intellectual Disability; ID, intellectual disability; VG, Dutch abbreviation for intellectual disability; ZZP, Zorgzwaartepakket, the Dutch classification of levels of support, care and/or treatment as a basis for long-term financing.

of reviewing medical files, administering questionnaires, physical examinations (with portable measuring equipment), fitness tests, observations, interviews, laboratory assessments and diaries. ${ }^{1}$ At the 3 -year follow-up, medical files were reviewed and professional caregivers completed questionnaires about the participant's health. Five years after the baseline measurements, causes of death were examined in the files of the deceased participants. The

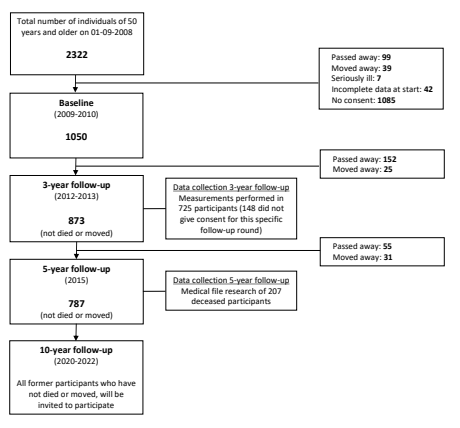

Figure 1 Number of participants in the Healthy Ageing and Intellectual Disability (HA-ID) cohort over time. Flow chart presents (1) the number of participants eligible for participation in the HA-ID cohort, (2) the number of participants who participated in measurements, (3) and the numbers of participants who dropped out the cohort.

participants themselves were not actively involved in the data collection for these follow-up measurements. At the 3-year and 5-year follow-ups, the cohort consisted of 873 and 787 participants, respectively.

All individuals with ID who participated in the baseline measurements and still receive care or support from one of the participating care organisations will be invited to participate in the 10-year follow-up measurements. There is one exclusion criterion: individuals are excluded from physical measurements if they are so seriously ill that participating in the study is not desirable. This decision is made based on shared decision making with caregivers and professionals. Based on previous mortality rates and historical lost to follow-up, it is estimated that 424 participants from the HA-ID cohort could be invited to participate in the 10-year follow-up measurements. With a conservative inclusion rate estimate of $50 \%$, approximately 212 participants are expected to actually participate in these measurements.

\section{Informed consent procedure}

Because not all individuals with ID are mentally capable of giving informed consent, two separate consent procedures are followed. A behavioural scientist evaluates whether the individual is able to understand the specifically designed study information to let them make an informed decision about participation. If an individual is capable of making an informed decision, an easy-to-read information letter with supporting pictures and a consent form will be sent to this individual. If the behavioural scientist assesses the individual as being unable to make an informed decision about participation, an information letter and consent form will be sent to the legal representative of this individual. The professional caregiver of the individual with ID is informed about the study and the informed consent procedure to support the individual or legal representative in making their decision for participation. 
Inclusion of the participants started in July 2020 and the data collection in October 2020. Both the inclusion and the data collection are still ongoing.

\section{Research themes}

An outline is presented of the published results for each research theme, followed by a description of the data collection for the 10-year follow-up, with a specific focus on newly added measurements. In the 10-year follow-up, we also omitted measurements that turned out to be unfeasible, invalid or unreliable, based on the baseline measurements. For clarity, these measurements are not listed separately below. An overview of all measurements at baseline and the 3,5 and 10-year follow-ups can be found in table 2 .

\section{Cardiovascular disease}

The HA-ID study provided many insights into the prevalence of CVD risk factors and the incidence of CVD in older adults with ID. The prevalences of hypertension $(53.0 \%)$, diabetes $(13.7 \%)$, metabolic syndrome $(44.7 \%)$ and chronic kidney disease $(15.3 \%)$ were similarly to those in the general population. ${ }^{3031}$ However, the prevalence of peripheral arterial disease $(20.7 \%)$ and obesity in women $(25.6 \%)$ as measured by the body mass index (BMI) was significantly higher than in the general population. ${ }^{10} 32$ The incidence of newly diagnosed CVD during a 3-year follow-up period was also examined. Incidence rates for myocardial infarction (2.8 per 1000 person-years), stroke (3.2 per 1000 person-years) and heart failure (12.8 per 1000 person-years) were similar to the general population. ${ }^{23}$ The use of atypical antipsychotics, chronic kidney disease, abdominal obesity and histories of stroke and heart failure turned out to be predictive for developing CVD during the 3-year follow-up period. ${ }^{23}$

The baseline measurements revealed underdiagnosis of CVD risk factors in the HA-ID cohort. For example, 54\% of the participants with diabetes had not been previously diagnosed with this condition. This was the case in $46 \%$ of the participants for hypercholesterolaemia, in 50\% for hypertension and in $94 \%$ for metabolic syndrome. ${ }^{30}$ Atypical presentation of symptoms, limitations in communication, limited cooperation and resilience make diagnostics in people with ID more challenging. ${ }^{33}$ This makes underdiagnosis a common problem in people with ID. ${ }^{44}$ The incidence of CVD described above is therefore also probably underestimated. ${ }^{23}$

With increasing longevity and increased prevalence of some CVD risk factors, people with ID may be at higher risk of developing CVD. The 10-year follow-up of the HA-ID cohort provides opportunities to learn more about CVD risk factors and the development of CVD over time in older adults with ID. The planned measurements for the 10-year follow-up are summarised in table 2 . The presence of CVD risk factors, CVD and CVD treatments/interventions over the past ten years will be assessed by reviewing the medical files of all participants who participated in the baseline measurements, including the medical files of deceased participants.

Blood will be collected through venepuncture. Blood will be stored for 15 years at $-80^{\circ} \mathrm{C}$, allowing analyses of relevant biochemical markers now and in the future (table 2).

The following measurements were added to the physical examination to gain more insight into the presence of CVD and its risk factors. Body composition will be studied with bioelectrical impedance analysis using the Tanita Body Composition Analyser (Tanita DC-430 MA, Tanita, Netherlands). An ECG will be performed to examine heart conditions. In addition, heart rate variability will be measured as a marker for the autonomic nervous system by wearing a heart rate monitor (Polar Vantage V HR H10, Polar Electro Oy, Finland) at rest for $5 \mathrm{~min}$. Finally, various haemodynamic measurements (mean arterial pressure, pulse pressure, resting heart rate, stroke volume, cardiac output, cardiac index, augmentation index, peripheral vascular resistance and pulse wave velocity) will be obtained with a non-invasive electronic blood pressure oscillometric monitoring system (MobilO-Graph 24h PWA Monitor, I.E.M. GmbH, Germany). ${ }^{35}$ Adding the Mobil-O-Graph provides a clearer picture of the presence of arterial stiffness and central systolic blood pressure, two important risk factors for CVD and morbidity. ${ }^{36}$

\section{Physical activity, fitness and musculoskeletal disorders}

The HA-ID study yielded important results about physical activity and fitness. Older adults with ID had very low physical activity and fitness levels. ${ }^{12}{ }^{14}$ In short, most participants were categorised as 'low active' (5000-7449 steps/day; 25.3\%) or 'sedentary' (<5000 steps/day; $38.5 \%$ ). Only $36.2 \%$ of the participants walked $\geq 7500$ steps/day. ${ }^{12}$ These results are likely to underestimate the problem because physical activity levels were only measured in participants who were physically able to walk at a sufficiently high speed for the pedometers to provide reliable measurements. In addition to these low physical activity levels, people with ID aged 50 and over had physical fitness levels comparable to or worse than people in the general population aged 70 and over. ${ }^{13} 14$ Data from the 3-year and 5-year follow-ups showed that these low physical fitness levels at baseline were indicative of a decline in daily functioning and mobility over the 3-year follow-up period and a higher mortality risk over the 5-year follow-up period. ${ }^{20-22} 37$ Additionally, it was found that being fit is more important for survival than obesity. People who were unfit had a mortality risk four times higher than people who were fit, regardless of obesity. ${ }^{37}$ Because of the importance of physical fitness, suitable fitness tests for this population are essential. Based on our previous research examining the reliability and feasibility of eight physical fitness tests in older adults with ID $^{38} 39$ we developed the ID-fitscan to assess the physical fitness levels of adults with ID. ${ }^{24}$ 
Table 2 Measurements within the HA-ID study: baseline, 3, 5 and 10-year follow-up per research theme

\begin{tabular}{|c|c|c|c|c|c|c|}
\hline \multirow[b]{2}{*}{ Type } & \multirow[b]{2}{*}{ Outcome } & \multirow[b]{2}{*}{ Details } & \multicolumn{3}{|c|}{ Moment of data collection } & \multirow[b]{2}{*}{$\begin{array}{l}\text { 10-year } \\
\text { follow up } \\
(2020-2022)\end{array}$} \\
\hline & & & $\begin{array}{l}\text { Baseline } \\
\text { measurements } \\
(2009-2010)\end{array}$ & $\begin{array}{l}\text { 3-year } \\
\text { follow up } \\
\text { (2012-2013) }\end{array}$ & $\begin{array}{l}5 \text {-year } \\
\text { follow up } \\
(2015)\end{array}$ & \\
\hline \multicolumn{7}{|l|}{ Demographics } \\
\hline \multirow[t]{4}{*}{ Medical file } & Age & - & $x$ & $\mathrm{x}$ & $x$ & $x$ \\
\hline & Sex & - & $x$ & & & \\
\hline & Residential status & $\begin{array}{l}\text { Central setting (with or without } 24 \text {-hour support), community based } \\
\text { (with or without } 24 \text {-hour support), independent with ambulatory support } \\
\text { (by appointment), with relatives, with partner, independent. }\end{array}$ & $\mathrm{x}$ & & & $x$ \\
\hline & Level of care & Care Intensity Packages (Dutch ZZP-scores) ${ }^{77}$ & $x$ & $\mathrm{x}$ & & $x$ \\
\hline \multicolumn{7}{|c|}{ 1. Cardiovascular disease } \\
\hline \multirow{8}{*}{$\begin{array}{l}\text { Physical } \\
\text { assessment }\end{array}$} & Brachial blood pressure $^{\star}$ & Omron M7 (OMRON Healthcare, the Netherlands). & $x$ & & & \\
\hline & $\begin{array}{l}\text { Central blood pressure and } \\
\text { arterial stiffness }\end{array}$ & $\begin{array}{l}\text { Mobil-O-Graph 24h PWA Monitor (IEM GmbH, Germany) including } \\
\text { pulse wave velocity. }\end{array}$ & & & & $\mathrm{x}$ \\
\hline & Ankle-Arm-Index ${ }^{*}$ & $\begin{array}{l}\text { Omron M7 (OMRON Healthcare, the Netherlands) (arm). Boso classico } \\
\text { and 8-MHz Doppler probe (Huntleigh MD II, UK) (ankle). Ankle-arm- } \\
\text { index calculated: systolic blood pressure ankle divided by systolic } \\
\text { blood pressure arm. }\end{array}$ & $x$ & & & $\mathrm{x}$ \\
\hline & Heart rate variability & Polar Vantage V HR H10 (Polar Electro Oy, Finland). & & & & $x$ \\
\hline & $\begin{array}{l}\text { Electrical activity of the } \\
\text { heart }\end{array}$ & ECG. & & & & $x$ \\
\hline & Fat percentage & $\begin{array}{l}\text { Formulas Durnin and Womersly }{ }^{78} \text { for calculating fat percentage from } \\
\text { the sum of four skinfolds: triceps, biceps, subscapular and suprailiacal. } \\
\text { Thickness of skinfolds measured with skinfold calliper (Harpenden, } \\
\text { Baty International, UK). }\end{array}$ & $x$ & & & $\mathrm{x}$ \\
\hline & & $\begin{array}{l}\text { Tanita Body Composition Analyser DC- } 430 \text { MA (Tanita, the } \\
\text { Netherlands). }\end{array}$ & & & & $x$ \\
\hline & Body composition & $\begin{array}{l}\text { Tanita Body Composition Analyser DC- } 430 \text { MA (Tanita, the } \\
\text { Netherlands). }\end{array}$ & & & & $x$ \\
\hline Venipuncture & Biochemical markers* & $\begin{array}{l}\text { Fasting plasma levels: glucose, cholesterol (total/HDL*/LDL), } \\
\text { haemoglobin*, haemoglobin A1c, triglyceride, } C \text { reactive protein, } \\
\text { interleukin } 6 \text {, Tumour Necrosis Factor alpha, albumin, vitamin } D \text {, } \\
\text { calcium, creatinine, cystatin } C \text {, troponin, N-terminal pro-B-type } \\
\text { natriuretic peptide etc. } \\
\text { The participants' blood is stored for } 15 \text { years at }-80^{\circ} \mathrm{C} \text {, in order to } \\
\text { perform additional analyses afterwards. }\end{array}$ & $x$ & & & $x$ \\
\hline \multirow[t]{2}{*}{ Medical file } & $C V D^{*}$ & $\begin{array}{l}\text { Presence of CVD (heart failure, myocardial infarction, stroke, } \\
\text { transient ischaemic attack, cardiac arrhythmias, angina pectoris, } \\
\text { aortic aneurysm, peripheral arterial disease, hypertension, etc), CVD } \\
\text { risk factors (diabetes mellitus, central obesity, metabolic syndrome, } \\
\text { rheumatoid arthritis, incriminating family history, etc) and treatments/ } \\
\text { interventions (revascularisation of the coronary artery, pacemaker and } \\
\text { implantable cardioverter-defibrillator). }\end{array}$ & $\mathrm{x}$ & $\mathrm{x}$ & & $x$ \\
\hline & Endocrine disorders* & $\begin{array}{l}\text { Presence of endocrine disorders (such as diabetes mellitus*, } \\
\text { hypercholesterolaemia and metabolic syndrome). }\end{array}$ & $x$ & & & $\mathrm{x}$ \\
\hline \multicolumn{7}{|c|}{ 2. Physical activity, fitness and musculoskeletal disorders } \\
\hline \multirow[t]{11}{*}{ Fitness assessment } & Manual dexterity* & Box and block test. ${ }^{79}$ & $x$ & & & $\mathrm{x}$ \\
\hline & Reaction time & Auditive and visual reaction time test. ${ }^{80} 81$ & $x$ & & & \\
\hline & Balance $^{\star}$ & Berg Balance Scale. ${ }^{82}$ & $\mathrm{x}$ & & & \\
\hline & & Comfortable and maximum walking speed $(5 \mathrm{~m}) .{ }^{24 *}$ & $x$ & & & $x$ \\
\hline & & Static balance test (for stances). ${ }^{24}$ & & & & $\mathrm{x}$ \\
\hline & Grip strength* & $\begin{array}{l}\text { Jamar Hand Dynamometer (\#5030J1, Sammons Preston Rolyan, } \\
\text { USA). }{ }^{24}\end{array}$ & $x$ & & & $x$ \\
\hline & Muscle endurance & 30 s chair stand. ${ }^{24}$ & $x$ & & & $x$ \\
\hline & & 5 times chair stand. ${ }^{24}$ & & & & $\mathrm{x}$ \\
\hline & $\begin{array}{l}\text { Cardiorespiratory } \\
\text { endurance }\end{array}$ & $\begin{array}{l}10 \mathrm{~m} \text { Incremental shuttle walking test. }{ }^{83} \text { Results of this test recalculated } \\
\text { to VO2max. }\end{array}$ & $x$ & & & \\
\hline & & $\begin{array}{l}2 \text { min step test, }{ }^{41} \text { with heart rate monitor (Polar RS } 400 \text {, Polar Electro } \\
\text { Oy, Finland). }\end{array}$ & & & & $\mathrm{X}$ \\
\hline & Flexibility & Extended version of Modified back saver sit and reach test. ${ }^{85} 86$ & $\mathrm{x}$ & & & \\
\hline
\end{tabular}


Table 2 Continued

\begin{tabular}{|c|c|c|c|c|c|c|}
\hline \multirow[b]{2}{*}{ Type } & \multirow[b]{2}{*}{ Outcome } & \multirow[b]{2}{*}{ Details } & \multicolumn{3}{|c|}{ Moment of data collection } & \multirow[b]{2}{*}{$\begin{array}{l}\text { 10-year } \\
\text { follow up } \\
(2020-2022)\end{array}$} \\
\hline & & & $\begin{array}{l}\text { Baseline } \\
\text { measurements } \\
(2009-2010)\end{array}$ & $\begin{array}{l}\text { 3-year } \\
\text { follow up } \\
(2012-2013)\end{array}$ & $\begin{array}{l}\text { 5-year } \\
\text { follow up } \\
(2015)\end{array}$ & \\
\hline \multirow{2}{*}{$\begin{array}{l}\text { Measurement at } \\
\text { home }\end{array}$} & \multirow[t]{4}{*}{ Physical activity } & Pedometer NL-1000 (New Lifestyles, USA). & $x$ & & & \\
\hline & & ActiGraph wGT3X-BT Accelerometer (ActiGraph, USA). & & & & $\mathrm{x}$ \\
\hline \multirow{8}{*}{$\begin{array}{l}\text { Questionnaires } \\
\text { professional } \\
\text { caregiver }\end{array}$} & & $\begin{array}{l}\text { Self-assembled questionnaire about the participants' habitual physical } \\
\text { activity. }\end{array}$ & $x$ & & & \\
\hline & & International Physical Activity Questionnaire - short version. ${ }^{40}$ & & & & $\mathrm{x}$ \\
\hline & $\begin{array}{l}\text { Activities of daily life/ } \\
\text { mobility }\end{array}$ & Animated Activity Questionnaire. ${ }^{51}$ & & & & $\mathrm{X}$ \\
\hline & Mobility $^{*}$ & $\begin{array}{l}\text { Self-assembled questionnaire based on the Hauser Ambulation Index } \\
\text { and the characteristics of the Gross Motor Function Classification } \\
\text { Scale. }^{88}\end{array}$ & $x$ & $\mathrm{x}$ & & $\mathrm{x}$ \\
\hline & Falling & $\begin{array}{l}\text { Self-assembled questionnaire about the number of falls in the last } \\
3 \text { months. }\end{array}$ & & $\mathrm{x}$ & & $\mathrm{x}$ \\
\hline & \multirow{2}{*}{$\begin{array}{l}\text { Symptoms/limitations } \\
\text { related to (hip/knee) OA }\end{array}$} & Hip disability and OA Outcome Score. ${ }^{5253}$ & & & & $\mathrm{x}$ \\
\hline & & Knee injury and OA Outcome Score. ${ }^{54}$ & & & & $\mathrm{x}$ \\
\hline & Use of lower extremity aids & $\begin{array}{l}\text { Self-assembled questions about the presence/use of aids for extra } \\
\text { support of the lower extremity (such as orthopaedic footwear, splints } \\
\text { and braces). }\end{array}$ & $x$ & & & $\mathrm{x}$ \\
\hline $\begin{array}{l}\text { Physical } \\
\text { assessment }\end{array}$ & Clinical/symptomatic OA & $\begin{array}{l}\text { Physical examination to examine the ACR criteria for clinical OA of the } \\
\text { hip and the knee. }{ }^{49} 89 \text { The following tests will be performed }{ }^{90}: \text { palpable } \\
\text { warmth of the knee joint, joint crepitus of the knee, bony enlargement } \\
\text { of the knee joint, quadriceps wasting, bone margin tenderness, } \\
\text { patellofemoral joint tenderness, anserine tenderness, tibiofemoral } \\
\text { joint tenderness, bulge sign of the knee, range of motion flexion and } \\
\text { extension of the knee, range of motion flexion and extension of the hip, } \\
\text { range of motion endorotation and exorotation of the hip. In addition, } \\
\text { the laxity of the joints will be tested }{ }^{91} \text { and the gait and the postural } \\
\text { alignment will be observed. }\end{array}$ & & & & $\mathrm{x}$ \\
\hline Interview & Self-report pain & $\begin{array}{l}\text { The participants undergo a comprehension test to test whether their } \\
\text { self-reported pain on a face-scale is a valid measurement. }{ }^{50} \text { When they } \\
\text { succeed they will be asked to grade their pain during examination of } \\
\text { the joint tenderness, flexion of the joints and hip internal rotation on a } \\
\text { face-scale. }\end{array}$ & & & & $\mathrm{x}$ \\
\hline Observation & Observed pain & $\begin{array}{l}\text { The healthcare professional will perform the Rotterdam Elderly Pain } \\
\text { Observation Scale (REPOS) to observe pain behaviour during the } \\
\text { physical examination for OA. A NRS-obs will be asked from the } \\
\text { professional caregiver as part of the REPOS observation. }{ }^{93}\end{array}$ & & & & $\mathrm{x}$ \\
\hline Medical imaging & Radiographic hip/knee OA & $\begin{array}{l}\text { X-rays of the hip and knee: anterior posterior (AP) view of both knees (if } \\
\text { possible weight-bearing), lateral view of right and left knee, skyline view } \\
\text { of the patellofemoral joint of right and left knee, AP view of pelvis, faux } \\
\text { profile view of right and left hip (only made by participants who are able } \\
\text { to stand up (with support)). }\end{array}$ & & & & $\mathrm{x}$ \\
\hline Medical file & Musculoskeletal disorders ${ }^{\star}$ & $\begin{array}{l}\text { Presence of musculoskeletal disorders in the medical file (such as OA, } \\
\text { scoliosis* }^{*} \text { spasticity and bone fractures). }\end{array}$ & $\mathrm{x}$ & & & $\mathrm{x}$ \\
\hline \multicolumn{7}{|c|}{ 3. Psychological problems and psychiatric disorders } \\
\hline \multirow{2}{*}{$\begin{array}{l}\text { Measurement at } \\
\text { home }\end{array}$} & \multirow{2}{*}{$\begin{array}{l}\text { Sleep-wake and circadian } \\
\text { rhythm }\end{array}$} & Actiwatch AW7 (Cambridge Technology Ltd, UK). & $x$ & & & \\
\hline & & GENEActiv Original (Activinsights Ltd, UK). & & & & $x$ \\
\hline \multirow[t]{5}{*}{ Interview } & Self-report depression & $\begin{array}{l}\text { Inventory of Depressive Symptomatology Self Report. }{ }^{94} \text { Phrasing of the } \\
\text { questions adapted to people with ID. }\end{array}$ & $x$ & & & $\mathrm{x}$ \\
\hline & \multirow[t]{2}{*}{ Self-report anxiety } & Glasgow Anxiety Scale for people with an Intellectual Disability. ${ }^{95}$ & $x$ & & & $x$ \\
\hline & & $\begin{array}{l}\text { Hospital Anxiety and Depression Scale-anxiety subscale. }{ }^{96} \text { Phrasing of } \\
\text { the questions adapted to people with ID. }\end{array}$ & $\mathrm{x}$ & & & \\
\hline & Quality of life & Intellectual Disability Quality of Life. ${ }^{97}$ & $\mathrm{x}$ & & & \\
\hline & $\begin{array}{l}\text { Diagnostic interview } \\
\text { depression and/or anxiety }\end{array}$ & $\begin{array}{l}\text { Participants with scores above the preset cut-off scores on one of } \\
\text { the depression or anxiety questionnaires are further examined using } \\
\text { the Psychiatric Assessment Schedule for Adults with Developmental } \\
\text { Disability ICD-10 version. Interviews are conducted with the participant } \\
\text { or his/her caregiver. }^{98}\end{array}$ & $x$ & & & $\mathrm{x}$ \\
\hline \multirow{4}{*}{$\begin{array}{l}\text { Questionnaires } \\
\text { professional } \\
\text { caregiver }\end{array}$} & $\begin{array}{l}\text { Informant-report depression } \\
\text { and anxiety }{ }^{*}\end{array}$ & Anxiety, Depression and Mood Scale..$^{9{ }^{*}}$ & $x$ & & & $\mathrm{x}$ \\
\hline & & Signaallijst Depressie Zwakzinnigen. ${ }^{100 *}$ & $\mathrm{x}$ & & & $\mathrm{x}$ \\
\hline & Somatic complaints & Somatic complaints subscale of the Symptom Checklist- $90 .{ }^{101}$ & $x$ & & & \\
\hline & Life-events & $\begin{array}{l}\text { Self-assembled checklist about life events based on other checklists, } \\
\text { earlier life event-studies and experience from professionals working } \\
\text { with people with ID. }\end{array}$ & $x$ & & & $x$ \\
\hline
\end{tabular}


Table 2 Continued

\begin{tabular}{|c|c|c|c|c|c|c|}
\hline \multirow[b]{2}{*}{ Type } & \multirow[b]{2}{*}{ Outcome } & \multirow[b]{2}{*}{ Details } & \multicolumn{3}{|c|}{ Moment of data collection } & \multirow[b]{2}{*}{$\begin{array}{l}\text { 10-year } \\
\text { follow up } \\
(2020-2022)\end{array}$} \\
\hline & & & $\begin{array}{l}\text { Baseline } \\
\text { measurements } \\
(2009-2010)\end{array}$ & $\begin{array}{l}\text { 3-year } \\
\text { follow up } \\
(2012-2013)\end{array}$ & $\begin{array}{l}\text { 5-year } \\
\text { follow up } \\
(2015)\end{array}$ & \\
\hline & Social outcome & $\begin{array}{l}\text { Self-assembled checklist about number of contacts with family, friends } \\
\text { and peers and visiting leisure clubs. }\end{array}$ & $x$ & & & \\
\hline & Cognitive functioning ${ }^{\star}$ & Dementia questionnaire for people with intellectual disabilities. ${ }^{102}$ & $x$ & & & $x$ \\
\hline & Aberrant behaviour & Aberrant Behaviour Checklist. ${ }^{60}$ & & & & $x$ \\
\hline & Sleep problems & $\begin{array}{l}\text { Self-assembled questions about sleep problems, including problems } \\
\text { with falling asleep and waking up early. }\end{array}$ & $x$ & & & $x$ \\
\hline & Sleep hygiene & $\begin{array}{l}\text { Self-assembled questions about sleep hygiene (such as sleeping } \\
\text { conditions, bedtimes, sleeping rituals, eating habits and use of } \\
\text { television, smartphone or tablet before going to bed and provided } \\
\text { professional support). }\end{array}$ & & & & $x$ \\
\hline Psychological file & $\begin{array}{l}\text { Psychological problems } \\
\text { and psychiatric disorders }\end{array}$ & $\begin{array}{l}\text { Baseline: level of intellectual disability, autism, depression, anxiety, } \\
\text { dementia, psychoses, other psychiatric disorders and serious } \\
\text { behavioural problems. } \\
\text { 10-year follow-up: baseline variables+mood disorders, autism } \\
\text { spectrum disorder, attention deficit hyperactivity disorder, obsessive- } \\
\text { compulsive disorder, attachment disorders, personality disorders, } \\
\text { psychotic disorders, post-traumatic stress disorder, cognitive disorders } \\
\text { (including dementia), traumatising and support or treatment received by } \\
\text { the participant. }\end{array}$ & $\mathrm{X}$ & & & $x$ \\
\hline Medical file & $\begin{array}{l}\text { Sleep disorders/sleep } \\
\text { problems }\end{array}$ & $\begin{array}{l}\text { Presence of sleep disorders/problems in the medical file (such as } \\
\text { problems with falling asleep and waking up early). }\end{array}$ & $x$ & & & $x$ \\
\hline $\begin{array}{l}\text { Physical } \\
\text { assessment }\end{array}$ & $\begin{array}{l}\text { Cortisol concentration last } \\
\text { month }\end{array}$ & $\begin{array}{l}\text { A small hair sample of at least } 1 \mathrm{~cm} \text { (length) will be taken from the } \\
\text { posterior vertex close to the scalp. }{ }^{103}\end{array}$ & & & & $x$ \\
\hline \multicolumn{7}{|c|}{ 4. Nutritional intake and nutritional state } \\
\hline \multirow{4}{*}{$\begin{array}{l}\text { Physical } \\
\text { assessment }\end{array}$} & Height* $^{\star}$ & - & $x$ & & & $\mathrm{x}$ \\
\hline & Weight $^{\star}$ & - & $\mathrm{X}$ & & & $\mathrm{X}$ \\
\hline & Body circumferences & Measuring tape for hip, calf* and upper arm circumference. & $x$ & & & $x$ \\
\hline & Bone quality ${ }^{*}$ & $\begin{array}{l}\text { Ultrasonometer (Lunar Achilles Insight, General Electric Healthcare, } \\
\text { USA) for measuring bone stiffness calcaneus. }\end{array}$ & $x$ & & & $x$ \\
\hline Diary & Food intake & Self-assembled 3 day food intake diary. & $x$ & & & $x$ \\
\hline $\begin{array}{l}\text { Meal time } \\
\text { observation }\end{array}$ & Dysphagia* $^{*}$ & Dysphagia Disorder Survey. ${ }^{67}$ & $x$ & & & $x$ \\
\hline \multirow{4}{*}{$\begin{array}{l}\text { Questionnaires } \\
\text { professional } \\
\text { caregiver }\end{array}$} & Malnutrition* & Mini Nutritional Assessment. ${ }^{104 *}$ & $x$ & & & $\mathrm{x}$ \\
\hline & & Short Nutritional Assessment Questionnaire for Residential Care. ${ }^{70}$ & & & & $x$ \\
\hline & Eating disorders ${ }^{\star}$ & Screening Tool of fEeding Problems. ${ }^{105}$ & $x$ & & & $\mathrm{x}$ \\
\hline & $\begin{array}{l}\text { Gastro-oesophageal reflux } \\
\text { disease }\end{array}$ & $\begin{array}{l}\text { Self-assembled questionnaire consisting of } 50 \text { items involving risk } \\
\text { factors and symptoms of gastro-oesophageal reflux disease. }\end{array}$ & $\mathrm{x}$ & & & \\
\hline Dental file & Dental condition & $\begin{array}{l}\text { Baseline: dental condition, premedication/sedation during check-up or } \\
\text { treatment, dental prosthesis and enamel wear. } \\
10 \text {-year follow-up: baseline variables + number of dentist/dental } \\
\text { hygienist visits, number of elements in the upper/lower jaw, dental } \\
\text { wear, dental caries, plastic restorations, crowns and bridges, implants, } \\
\text { gingivitis/periodontitis, mobile elements and loss of dental elements } \\
\text { due to trauma. }\end{array}$ & $x$ & & & $\mathrm{x}$ \\
\hline Medical file & Gastrointestinal diseases ${ }^{*}$ & 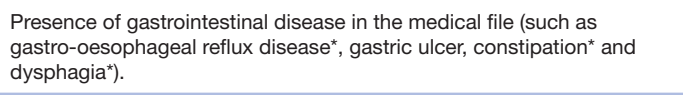 & $x$ & & & $\mathrm{x}$ \\
\hline \multicolumn{7}{|l|}{ 5. Frailty } \\
\hline \multicolumn{7}{|c|}{ All outcomes/measurements with an asterisk* in this table are part of the overarching research theme 'Frailty'. } \\
\hline \multicolumn{7}{|l|}{ General health data } \\
\hline \multirow[t]{8}{*}{ Medical file } & $\begin{array}{l}\text { Aetiology of intellectual } \\
\text { disability }\end{array}$ & $\begin{array}{l}\text { Presence of the aetiology of the intellectual disability in the medical file } \\
\text { (such as a specific genetic syndrome). }\end{array}$ & $\mathrm{x}$ & & & $x$ \\
\hline & Malignancies $^{*}$ & Presence of malignancies in the medical file. & $x$ & & & $x$ \\
\hline & Pulmonary diseases ${ }^{*}$ & $\begin{array}{l}\text { Presence of pulmonary disease in the medical file (such as asthma*, } \\
\text { chronic obstructive pulmonary disease }{ }^{\star} \text { and sleep apnoea syndrome). }\end{array}$ & $x$ & & & $x$ \\
\hline & Neurological disorders & $\begin{array}{l}\text { Presence of neurological disorders in the medical file (such as } \\
\text { dementia, epilepsy and Parkinson's disease). }\end{array}$ & $x$ & & & $\mathrm{x}$ \\
\hline & $\begin{array}{l}\text { Diseases of the } \\
\text { genitourinary system }\end{array}$ & $\begin{array}{l}\text { Presence of diseases of the genitourinary system in the medical file } \\
\text { (such as urinary tract infections, incontinence and renal failure). }\end{array}$ & $\mathrm{x}$ & & & $\mathrm{x}$ \\
\hline & $\begin{array}{l}\text { Visual and hearing } \\
\text { impairments }{ }^{\star}\end{array}$ & Presence of visual and hearing impairments in the medical file. & $\mathrm{x}$ & & & $\mathrm{x}$ \\
\hline & Medication use $^{*}$ & Medication use (medicament and dosage) as stated in the medical file. & $x$ & & & $\mathrm{x}$ \\
\hline & Hospitalisation ${ }^{\star}$ & Number of hospitalisations in the past period. & & $\mathrm{x}$ & & $x$ \\
\hline
\end{tabular}


Table 2 Continued

\begin{tabular}{|c|c|c|c|c|c|c|}
\hline \multirow[b]{2}{*}{ Type } & \multirow[b]{2}{*}{ Outcome } & \multirow[b]{2}{*}{ Details } & \multicolumn{3}{|c|}{ Moment of data collection } & \multirow[b]{2}{*}{$\begin{array}{l}\text { 10-year } \\
\text { follow up } \\
(2020-2022)\end{array}$} \\
\hline & & & $\begin{array}{l}\text { Baseline } \\
\text { measurements } \\
(2009-2010)\end{array}$ & $\begin{array}{l}\text { 3-year } \\
\text { follow up } \\
\text { (2012-2013) }\end{array}$ & $\begin{array}{l}\text { 5-year } \\
\text { follow up } \\
\text { (2015) }\end{array}$ & \\
\hline & Mortality & Date of death, as stated in the medical file. & & $\mathrm{x}$ & $x$ & $\mathrm{x}$ \\
\hline & Cause of death & Cause of death, as stated in the medical file. & & $\mathrm{x}$ & $\mathrm{X}$ & $\mathrm{X}$ \\
\hline \multirow{7}{*}{$\begin{array}{l}\text { Questionnaires } \\
\text { professional } \\
\text { caregiver }\end{array}$} & Activities of daily life ${ }^{*}$ & Barthel Index..$^{106 *}$ & $x$ & $\mathrm{x}$ & & $\mathrm{X}$ \\
\hline & $\begin{array}{l}\text { Instrumental activities of } \\
\text { daily life }\end{array}$ & $\begin{array}{l}\text { Questionnaire based on the Instrumental Activities of Daily Living of } \\
\text { Lawton and Brody }^{107} \text { and the Groningen Activities Restriction Scale. }{ }^{108}\end{array}$ & $x$ & $x$ & & $\mathrm{x}$ \\
\hline & Daytime activities* & $\begin{array}{l}\text { Self-assembled questions about daytime activities and/or work of the } \\
\text { participant. }\end{array}$ & $x$ & & & $\mathrm{x}$ \\
\hline & Smoking & $\begin{array}{l}\text { Self-assembled questions about the smoking habits of the participant } \\
\text { (how many cigars, cigarettes and/or pipe per day and past smoking } \\
\text { habits). }\end{array}$ & $x$ & & & $\mathrm{x}$ \\
\hline & Alcohol use & $\begin{array}{l}\text { Self-assembled questions about the participant's alcohol consumption } \\
\text { (alcohol use per day and alcohol use in the past). }\end{array}$ & $x$ & & & $\mathrm{x}$ \\
\hline & Drug use & $\begin{array}{l}\text { Self-assembled questions about the drug use of the participant (use of } \\
\text { cannabis and hard drugs per day and drug use in the past). }\end{array}$ & & & & $x$ \\
\hline & Use of caffeinated drinks & $\begin{array}{l}\text { Self-assembled questions about the use of caffeinated drinks (coffee, } \\
\text { tea, coke, energy drink and chocolate milk) by the participant. }\end{array}$ & & & & $x$ \\
\hline
\end{tabular}

"All outcomes/measurements with an asterisk" in this table are part of the overarching research theme 'Frailty'

ACR, American College of Rheumatology; CVD, cardiovascular disease; ECG, electrocardiogram; HDL, high-density lipoprotein; ICD-10, International Classification of Diseases 10th revision; LDL, low-density lipoprotein; NRS-obs, Numeric Rating Scale observation; OA, osteoarthritis; ZZP, Zorgzwaartepakket, the Dutch classification of levels of support, care and/or treatment as a basis for long-term financing.

In the 10-year follow-up measurements, physical activity and fitness levels will be assessed again (see table 2). Based on previous results and experiences, some changes were made to the measurements. Physical activity will be measured using the ActiGraph (wGT3X-BT Accelerometer, ActiGraph, USA), an instrument that can make measurements at very low walking speeds and provides more detailed information about the physical activity levels of the participant. Complementary to this, we will use the International Physical Activity QuestionnaireShort Form (IPAQ-SF) to collect physical activity data. ${ }^{40}$ The ID-fitscan, ${ }^{24}$ supplemented with the 2 min step test, ${ }^{41}$ will be used to assess physical fitness. Physical fitness tests that turned out to be less suitable at the baseline measurements are excluded. ${ }^{24}$

The 10-year follow-up will also focus on musculoskeletal disorders, in particular osteoarthritis. Osteoarthritis is common in older people in the general population, leading to pain, joint instability, limitations in daily activities and decreased quality of life. ${ }^{42} 43$ Little is known about the prevalence of knee and hip osteoarthritis in people with ID. High prevalence is expected because many factors that have been associated with osteoarthritis (such as obesity, poor physical fitness levels, poor motor skills, gait abnormalities, musculoskeletal complications and developmental problems) are more common in adults with ID than in the general population. ${ }^{1444-48}$

Osteoarthritis of the hip and the knee will be assessed by applying the American College of Rheumatology (ACR) criteria for the diagnosis of osteoarthritis. These criteria cover clinical symptoms, consisting of pain and functional limitations of the joint and include radiological characteristics from X-rays as well. ${ }^{49}$ The 10 -year follow-up includes several tests to identify the presence of the ACR criteria, including physical examinations with pain observations (Rotterdam Elderly Pain Observation Scale (REPOS) filled out by the health professional performing the physical examination, supplemented by a Numeric Rating Scale observation filled out by the professional caregiver during the physical examination and a face-scale for selfreport of pain ${ }^{50}$ ). The REPOS will also be used to assess pain during rest and daily activities that may provoke osteoarthritis complaints. Also, the Animated Activity Questionnaire will be used to identify whether the participants have complaints due to osteoarthritis during daily living activities, filled out by the professional caregivers of the participants. ${ }^{51}$ Additional, data about gait characteristics that may be related to osteoarthritis will be collected through a structured observation. To signal pain, stiffness and range of motion the standardised questionnaires (the Hip disability and Osteoarthritis Outcome Score ${ }^{52} 53$ and the Knee disability and Osteoarthritis Outcome Score ${ }^{54}$ ) will be used.

\section{Psychological problems and psychiatric disorders}

At baseline, data were collected on the prevalence of depression and anxiety disorders. The prevalence of major depressive disorder was $7.6 \%,{ }^{8}$ which is higher than in the general population $(1.8 \%-4.0 \%) .{ }^{55}$ Only $4.4 \%$ of the participants met the criteria for one of the anxiety disorders. ${ }^{8}$ This was lower than expected and lower than the prevalence in the general population $(10.2 \%-$ $11.6 \%) .{ }^{56}$ This may be explained by the fact that proxy reports had to be used in $78 \%$ of the participants. It is difficult for respondents such as professional caregivers to recognise symptoms of anxiety (eg, pounding heart, worrying). This may have led to underestimation of the prevalence of anxiety disorders. 
In the general population, there is a strong association between sleep problems and anxiety and mood disorders. ${ }^{57}$ Data on sleep and sleep-wake rhythm were, therefore, also collected at baseline based on wrist-worn accelerometry (Actiwatch AW7, Cambridge Technology Ltd, Cambridge, $\mathrm{UK}^{49}{ }^{50}$ ). It was found that $23.9 \%$ of the participants lay awake for more than 1 hour before falling asleep. In addition, $63.1 \%$ lay awake for more than $90 \mathrm{~min}$ after sleep onset and before final morning awakening, $20.9 \%$ slept less than 6 hours and $9.3 \%$ were already awake for more than $60 \mathrm{~min}$ before getting out of bed. ${ }^{58}$ In total $72.1 \%$ of the participants were classified as having at least one of these sleep problems. ${ }^{58}$

During the 10-year follow-up, data about anxiety disorders, depression and sleep will be collected again, with some changes and additions to the baseline data collection (see table 2). The 10-year follow-up has been extended with data retrieval from the psychological files about the presence of mood disorders, autism spectrum disorder, attention deficit hyperactivity disorder, obsessive-compulsive disorder, attachment disorders, personality disorders, psychotic disorders, post-traumatic stress disorder and cognitive disorders (including dementia). In older people with ID, there is an association between the presence of a mental health diagnosis and problem behaviour. ${ }^{59}$ Data about problem behaviour will, therefore, also be collected within the 10-year follow-up using the Aberrant Behaviour Checklist (ABC) ${ }^{60}$ The ABC is a widely used behaviour rating scale and measures problem behaviour using five subscales: irritability, lethargy, stereotypy, hyperactivity and excessive speech. In addition, a potential objective biomarker for long-term stress in people with ID will be evaluated, which may help to future diagnostic assessment. Long-term stress over the recent months will be retrospectively examined with a hair cortisol measurement. Recently published studies in the general population indicate that there is a strong association between the level of hair cortisol, life events and symptoms of anxiety and depression. ${ }^{61-64}$

Data on sleep and sleep-wake rhythm will still be collected with accelerometry; however, we will now use the GENEActiv (Original, Activinsights Ltd, UK). Data from the GENEActiv are comparable to data collected by the Actiwatch that was used at baseline. ${ }^{65}$ Extra questions about sleep hygiene and sleep circumstances have been added to learn more about the influence of these factors on sleep in older adults with ID.

\section{Nutritional intake and nutritional state}

The baseline measurements of the HA-ID study yielded insights into the dietary intake and nutritional state of older adults with ID. Three-day dietary records completed by professional caregivers revealed inadequate dietary intake, with none of the participants meeting all Dutch recommendations for a healthy dietary intake. The food intake was too low in calories in $68.6 \%$ of the participants, too low in protein in $30.2 \%$, too low in dietary fibre in $98.2 \%$ and too high in saturated fat in $89.5 \%$ of the participants. ${ }^{11}$ Forty-two per cent of the participants had vitamin D deficiency, of which $9 \%$ had severe vitamin D deficiency. ${ }^{66}$ Vitamin D supplement were routinely provided to $45 \%$ of the participants and this group had significantly higher mean vitamin $\mathrm{D}$ serum levels than those without supplement. This calls for more attention for prescribing vitamin $\mathrm{D}$ in older adults with ID. ${ }^{66}$ These results also indicate that there is plenty of room for improvement in healthy nutrition.

Mealtime observations using the Dysphagia Disorder Survey ${ }^{67}$ showed moderate to severe dysphagia in $51.7 \%$ of the participants, which is comparable to the prevalence in nursing homes. ${ }^{9}$ In $89.5 \%$ of the participants with dysphagia, this had not been previously diagnosed. The high degree of underdiagnosis illustrates the importance of screening and diagnosing dysphagia to prevent complications in clinical practice. Greater age, Down syndrome, mobility impairment, needing help with feeding and use of benzodiazepines were positively and independently associated with dysphagia. ${ }^{9}$

The prevalence of sarcopenia was also studied. Fourteen per cent of the participants were classified as having sarcopenia, which developed at a relatively young age compared with the general population. At a prevalence of $12.7 \%$, sarcopenia was already significantly present in participants aged 50-64. ${ }^{68}$ Additionally, the bone quality was low in $43.9 \%$ of participants. Being female, greater age, more severe ID, mobility impairment and anticonvulsant drug use were positively associated with low bone quality ${ }^{69}$ Higher BMI was negatively associated with low bone quality. ${ }^{69}$ These results suggest an approach for periodic screening of high-risk groups for low bone quality and target groups for prevention in clinical practice. $^{69}$

In the 10-year follow-up, the baseline measurements will be repeated (see table 2). To gain a better picture of the degree of malnutrition among older adults with ID, the Short Nutritional Assessment Questionnaire for Residential Care (SNAQRC) will be added to the data collection. The SNAQRC is a screening instrument for early detection of undernutrition in nursing or residential home settings using a traffic light system in which BMI and four questions related to involuntary weight loss, loss of appetite and eating with help are combined. ${ }^{70}$ The SNAQRC will be completed by professional caregivers.

At baseline, a short dental file examination provided some data on the dental condition of the participants. To get a comprehensive picture of the dental condition and dental hygiene of older adults with ID, the dental file review will be extended. Data will be collected about dental condition, premedication and sedation during check-up and treatment, dental prosthesis, enamel wear, the number of dentist and dental hygienist visits, the number of elements in the upper and lower jaw, dental wear, dental caries, plastic restorations, crowns and bridges, implants, gingivitis and periodontitis, mobile elements and loss of dental elements due to trauma. 


\section{Frailty}

Frailty is a clinically recognisable state of increased vulnerability resulting from age-associated decline in reserves and functions across multiple physiological systems. ${ }^{71}$ Frailty leads to deterioration of daily functioning and mobility, increased disability, development of comorbidity and increased care intensity. ${ }^{17} 7273$ As a result, signalling frailty could play a valuable role in care planning, potentially improving quality of life and increasing the life expectancy of frail people with ID. In the general population, frailty is usually measured by tools such as the frailty phenotype. ${ }^{74}$ However, we theorised that the ID population might require a more specific approach than the available tools allow. Based on the baseline data, an ID-Frailty Index was created consisting of 51 items. ${ }^{3}$ The ID-Frailty Index focuses on multiple aspects of daily functioning, opposed to a broader focus on physical frailty and mobility impairment. ${ }^{75}$ As a result, the ID-Frailty Index could be applied to a larger proportion of the study population than the frailty phenotype and was deemed more suitable for measuring frailty in older adults with ID. ${ }^{75}$ Furthermore, the ID-Frailty index showed a stronger relationship with mortality than the frailty phenotype. ${ }^{75}$ The 3-year follow-up data showed that higher scores on the ID-Frailty Index resulted in a greater risk of death. ${ }^{19}$ Finally, the ID-Frailty Index was predictive for a decline in mobility and increases in disability, polypharmacy and care intensity. ${ }^{16-18}$

In the 10-year follow-up, all previous measurements that were used to create the ID-Frailty index will be repeated (see table 2). This lets us investigate the characteristics of frailty over time. In an attempt to further increase the practical and clinical usability of the ID-Frailty Index, a shortened version was developed. During the 10-year follow-up, the utility of this short form of the ID-Frailty Index will be further investigated.

\section{General health data}

In addition to these five research themes, data on other health variables will also be collected such as data on other diseases, medication use, hospitalisation, mortality, activities of daily life, smoking and alcohol/drug use (table 2, under the heading 'General health data').

\section{Procedure}

To limit the burden and impact on participants and their professional caregivers, all measurements will be done in settings close to where the participants live. All measurements will be carried out by test administrators consisting of professionals working in the care organisations. All test administrators will be trained to ensure accurate administration and correct scoring of the measurements. All measurements for a specific participant will be scheduled within 1 week. This test week consists of a physical examination performed by medical staff, fitness tests supervised by movement therapists or physiotherapists, observations to assess pain during activities of daily life performed by trained healthcare professionals, a mealtime observation to screen for dysphagia performed by speech and language therapists and a maximum of two interviews by trained and qualified professionals aimed at screening and diagnosing anxiety and depression. The participant will wear portable measuring equipment on the wrist and hip for 7 days to monitor physical activity and sleep-wake rhythm. If separate consent is provided, blood samples and a tuft of scalp hair will be collected. For logistical reasons, the hip and knee X-rays take place outside this test week. All measurements together require a maximum time investment of 4 hours for each participant. However, the time investment per participant will probably vary because not every participant can undergo all measurements. The study will not interfere with routine medical practice. In addition to measurements for which active involvement of the participants is needed, the professional caregiver will be asked to complete questionnaires about the participant's health and data will be collected from the medical, psychological and dental files. The medical file review is performed using the records of all participants who participated in the baseline measurements, including the medical files of deceased participants. A complete overview of all measurements within the HA-ID study can be found in table 2. After the test week, the participant's physician and behavioural scientist receive a report with a summary of the results of the measurements.

\section{Patient and public involvement}

Patients and the public were not involved in the design of this study.

\section{Statistical analysis}

In line with the previous measurements, the 10-year follow-up will provide cross-sectional and longitudinal data. Various statistical analyses will be applied. Descriptive statistics are used to answer questions about the prevalence and incidence of health conditions and possible risk factors. Multivariable regression analyses are used to answer questions about differences between subgroups and associations between variables, considering possible confounders and to adjust for these covariates. Survival analysis with Cox proportional hazard models will be used to investigate relationships between various factors (including age, sex, level of ID and comorbidity) and several health conditions and mortality over time. For repeated measurements, the dependency of measurements for the same participant will be adjusted by using generalised linear mixed-effects models.

\section{Implications for practice}

The HA-ID study so far has yielded knowledge of various health problems that are prevalent in older adults with ID, and how these compare to the general population. This knowledge suggested approaches for improving care for adults with ID. The 10-year follow-up will provide a deeper understanding of the course of health over time and risk factors for health problems in older adults with ID. Research into CVD risk factors in this population, for 
example, is still very limited. More knowledge about CVD risk factors and possible group-specific risk factors will give a better estimate of the cardiovascular risk profile of older adults with ID. The 10-year follow-up will also give a clearer picture of how frailty develops over time and whether there are certain groups of people with ID who are at higher risk for adverse outcomes.

What characterises the HA-ID study is that it is a prospective multicentre cohort study in which, compared with other ID studies, a relatively large $(n=1050)$ and heterogeneous group of older adults with ID is followed over time. The extensive measurements let us evaluate the health of older adults with ID from a broad perspective and investigate the interrelationships between medical domains such as CVD, physical fitness, psychological problems and psychiatric disorders, nutrition and frailty. Looking across research themes is especially important because multi-morbidity is common in people with ID. ${ }^{4}$

We know from experience that conducting epidemiological research into this field can be difficult and involves challenges in selecting suitable measuring instruments; some require certain levels of cognitive, physical or verbal ability that may not be compatible with those of the participants. To allow for optimal comparison between the general population and our cohort, we have aligned the measurements of the 10-year follow-up as much as possible to existing cohort studies of (specifically older) adults in the general population. However, feasibility, validity and reliability in older adults with ID were the leading criteria when selecting measuring instruments, using previously acquired knowledge and experience from the HA-ID study. How invasive and time-consuming instruments are was also considered, as were the feasibility for a large proportion of our population, the extent to which it is possible to do the measurement at the care organisations and the extent to which the instruments can be used by a large group of professionals without making concessions in terms of interrater reliability. In addition, the costs of the measuring instruments were examined, considering use in clinical practice. The HA-ID study is continuously searching for innovative and feasible measuring instruments that can be implemented for data collection.

A limitation of our study is that financial and feasibility reasons mean it has not been possible to perform follow-up measurements more regularly. Fortunately, the presence of routine registrations performed by the care organisations in medical, psychological and dental files lets us retrospectively collect data on the health of the participants over the past 10 years. Given the age of our study population and the length of follow-up, selection bias caused by the survival of healthier participants may distort our results. We are aware of this healthy survivor effect and address this when analysing and interpreting our results. It should be noted, that we do have access to the medical files of participants who have passed away. This lets us retrospectively collect data on the health of this group.
Results from the 10-year follow-up measurements are important for prioritising policy and care and underpinning clinical decision making about screening, prevention and treatment to improve healthy ageing of adults with ID. Longitudinal data collected in the 10-year follow-up of the HA-ID cohort therefore has high added value.

\section{Ethics and dissemination}

As for the previous parts of the HA-ID study (MEC2008-234 and MEC-2011-309), ethical approval for the 10-year follow-up has been obtained from the Medical Ethics Review Committee of the Erasmus MC, University Medical Centre Rotterdam (MEC-2019-0562). ${ }^{76}$ Local ethical committees and boards of individuals with ID and their representatives of the three involved care organisations were informed.

Acknowledgements The authors thank the care organisations, Abrona, Amarant and Ipse de Bruggen, involved in the HA-ID consortium for their collaboration and financial and organisational support. We would also like to thank the professionals of these organisations as well as all participants, their family members and caregivers for their valuable contribution to the HA-ID study so far.

Contributors We would like to justify the authors' contribution by describing their involvement in the different phases of the writing process: (1) devising and shaping the research project (AO, TIMH and DAMMF), (2) drafting the study protocol (MJdL, A0, RGE and MWEJK), (3) writing the first draft of the manuscript (MJdL), (4) critically revising the manuscript (AO, RGE, MWEJK, MCvM, MCVB, TIMH, PJEB, DAMMF) and (5) drafting the manuscript, tables and figures to their final version (MJdL, A0 and RGE). All authors have critically reviewed the content of this paper and have approved the final version of the manuscript.

Funding This work is supported by ZonMw grant number 839180001 . In addition to external funding, the 10-year follow-up of the HA-ID study is funded by the three Dutch care organisations, Abrona, Amarant and Ipse de Bruggen, involved in the HA-ID consortium and the department of General Practice of the Erasmus MC, University Medical Centre Rotterdam, the Netherlands.

Competing interests None declared.

Patient consent for publication Not applicable.

Provenance and peer review Not commissioned; externally peer reviewed.

Supplemental material This content has been supplied by the author(s). It has not been vetted by BMJ Publishing Group Limited (BMJ) and may not have been peer-reviewed. Any opinions or recommendations discussed are solely those of the author(s) and are not endorsed by BMJ. BMJ disclaims all liability and responsibility arising from any reliance placed on the content. Where the content includes any translated material, BMJ does not warrant the accuracy and reliability of the translations (including but not limited to local regulations, clinical guidelines, terminology, drug names and drug dosages), and is not responsible for any error and/or omissions arising from translation and adaptation or otherwise.

Open access This is an open access article distributed in accordance with the Creative Commons Attribution Non Commercial (CC BY-NC 4.0) license, which permits others to distribute, remix, adapt, build upon this work noncommercially, and license their derivative works on different terms, provided the original work is properly cited, appropriate credit is given, any changes made indicated, and the use is non-commercial. See: http://creativecommons.org/ licenses/by-nc/4.0/.

\section{ORCID iDs}

Marleen J de Leeuw http://orcid.org/0000-0002-6357-6213

Alyt Oppewal http://orcid.org/0000-0001-6630-8807

Roy G Elbers http://orcid.org/0000-0002-4850-6954

Marco C van Maurik http://orcid.org/0000-0002-9295-1940

Marjoleine C van Bruggen http://orcid.org/0000-0003-3026-0164

Thessa I M Hilgenkamp http://orcid.org/0000-0001-9882-163X

Patrick J E Bindels http://orcid.org/0000-0001-5941-4820

Dederieke A M Maes-Festen http://orcid.org/0000-0002-7613-0720 


\section{REFERENCES}

1 Hilgenkamp TIM, Bastiaanse LP, Hermans $\mathrm{H}$, et al. Study healthy ageing and intellectual disabilities: recruitment and design. Res Dev Disabil 2011;32:1097-106.

2 Oppewal A, Schoufour JD, van der Maarl HJK, et al. Causes of mortality in older people with intellectual disability: results from the HA-ID study. Am J Intellect Dev Disabil 2018;123:61-71.

3 Schoufour JD, Mitnitski A, Rockwood K, et al. Development of a frailty index for older people with intellectual disabilities: results from the HA-ID study. Res Dev Disabil 2013;34:1541-55.

4 Hermans H, Evenhuis HM. Multimorbidity in older adults with intellectual disabilities. Res Dev Disabil 2014;35:776-83.

5 Schoufour JD, Echteld MA, Evenhuis HM. Kwetsbaarheid bij ouderen met een verstandelijke beperking: operationalisering, risico en opsporing [Frailty in people with intellectual disabilities: operationalization, risks and detection]. Tijdschr Gerontol Geriatr 2015;46:92-103.

6 Schoufour JD, Oppewal A, van der Maarl HJK, et al. Multimorbidity and polypharmacy are independently associated with mortality in older people with intellectual disabilities: a 5-year follow-up from the HA-ID study. Am J Intellect Dev Disabil 2018;123:72-82.

7 Maaskant M, van de Wouw E, van Wijck R, et al. Circadian sleepwake rhythm of older adults with intellectual disabilities. Res Dev Disabil 2013;34:1144-51.

8 Hermans H, Beekman ATF, Evenhuis HM. Prevalence of depression and anxiety in older users of formal Dutch intellectual disability services. J Affect Disord 2013;144:94-100.

9 Bastiaanse LP, van der Kamp A, Evenhuis HM, et al.. Dysphagia in older people with intellectual disabilities: results of the HA-ID study, 2014. Available: https://www.semanticscholar.org/paper/Nutrition\% 2C-Nutritional-State-and-Related-Conditions-Bastiaanse/f8f32397 8e80a9a85693d346d1d2ace66cfc3898 [Accessed 23 Dec 2020].

10 de Winter CF, Bastiaanse LP, Hilgenkamp TIM, et al. Overweight and obesity in older people with intellectual disability. Res Dev Disabil 2012;33:398-405.

11 Bastiaanse LP, Evenhuis HM, Odekerken M, et al.. Inadequate dietary intake in older people with intellectual disabilities: results of the HA-ID study, 2014. Available: https://www.semanticscholar org/paper/Nutrition\%2C-Nutritional-State-and-Related-ConditionsBastiaanse/f8f323978e80a9a85693d346d1d2ace66cfc3898 [Accessed 23 Dec 2020].

12 Hilgenkamp TIM, Reis D, van Wijck R, et al. Physical activity levels in older adults with intellectual disabilities are extremely low. Res Dev Disabil 2012;33:477-83.

13 Oppewal A, Hilgenkamp TIM, van Wijck R, et al. Feasibility and outcomes of the Berg balance scale in older adults with intellectual disabilities. Res Dev Disabil 2013;34:2743-52

14 Hilgenkamp TIM, van Wijck R, Evenhuis HM. Low physical fitness levels in older adults with ID: results of the HA-ID study. Res Dev Disabil 2012;33:1048-58.

15 Hilgenkamp TIM, van Wijck R, Evenhuis HM. Subgroups associated with lower physical fitness in older adults with ID: results of the HAID study. Res Dev Disabil 2014;35:439-47.

16 Schoufour JD, Echteld MA, Bastiaanse LP, et al. The use of a frailty index to predict adverse health outcomes (falls, fractures, hospitalization, medication use, comorbid conditions) in people with intellectual disabilities. Res Dev Disabil 2015;38:39-47.

17 Schoufour JD, Mitnitski A, Rockwood K, et al. Predicting disabilities in daily functioning in older people with intellectual disabilities using a frailty index. Res Dev Disabil 2014;35:2267-77.

18 Schoufour JD, Evenhuis HM, Echteld MA. The impact of frailty on care intensity in older people with intellectual disabilities. Res Dev Disabil 2014;35:3455-61.

19 Schoufour JD, Mitnitski A, Rockwood K, et al. Predicting 3-year survival in older people with intellectual disabilities using a frailty index. J Am Geriatr Soc 2015;63:531-6.

20 Oppewal A, Hilgenkamp TIM, van Wijck R, et al. Physical fitness is predictive for a decline in daily functioning in older adults with intellectual disabilities: results of the HA-ID study. Res Dev Disabil 2014;35:2299-315.

21 Oppewal A, Hilgenkamp TIM, van Wijck R, et al. Physical fitness is predictive for a decline in the ability to perform instrumental activities of daily living in older adults with intellectual disabilities: results of the HA-ID study. Res Dev Disabil 2015;41-42:76-85.

22 Oppewal A, Hilgenkamp TIM. Physical fitness is predictive for 5 year survival in older adults with intellectual disabilities. J Appl Res Intellect Disabil 2019;32:958-66.

23 de Winter CF, van den Berge APJ, Schoufour JD, et al. A 3-year follow-up study on cardiovascular disease and mortality in older people with intellectual disabilities. Res Dev Disabil 2016;5354:115-26.
24 Oppewal A, Hilgenkamp TIM. Adding meaning to physical fitness test results in individuals with intellectual disabilities. Disabil Rehabil 2020;42:1406-13

25 Hermans $\mathrm{H}$, Jelluma $\mathrm{N}$, van der $\mathrm{Pas} \mathrm{FH}$, et al. Feasibility, reliability and validity of the Dutch translation of the anxiety, depression and mood scale in older adults with intellectual disabilities. Res Dev Disabil 2012;33:315-23.

26 McCarron M, Swinburne J, Burke E, et al. Patterns of multimorbidity in an older population of persons with an intellectual disability: results from the intellectual disability supplement to the Irish longitudinal study on aging (IDS-TILDA). Res Dev Disabil 2013;34:521-7.

27 Chitty KM, Evans E, Torr JJ, et al. Central nervous system medication use in older adults with intellectual disability: results from the successful ageing in intellectual disability study. Aust N Z J Psychiatry 2016;50:352-62.

28 Coppus A, Evenhuis H, Verberne G-J, et al. Dementia and mortality in persons with Down's syndrome. J Intellect Disabil Res 2006;50:768-77.

29 Woittiez I, Crone F. Zorg voor verstandelijk gehandicapten. Ontwikkelingen in de vraag. The Hague, the Netherlands: CPB Centraal Cultureel Planbureau, 2005.

30 de Winter CF, Bastiaanse LP, Hilgenkamp TIM, et al. Cardiovascular risk factors (diabetes, hypertension, hypercholesterolemia and metabolic syndrome) in older people with intellectual disability: results of the HA-ID study. Res Dev Disabil 2012;33:1722-31.

31 de Winter CF, Echteld MA, Evenhuis HM. Chronic kidney disease in older people with intellectual disability: results of the HA-ID study. Res Dev Disabil 2014;35:726-32.

32 de Winter CF, Bastiaanse LP, Kranendonk SE, et al. Peripheral arterial disease in older people with intellectual disability in the Netherlands using the Ankle-brachial index: results of the HA-ID study. Res Dev Disabil 2013;34:1663-8.

33 van Eeghen AM, Huisman SA, van Goethem G, et al.. Somatische comorbiditeit bij kinderen en volwassenen met een verstandelijke beperking en een psychiatrische aandoening [Somatic comorbidity in children and adults with intellectual disability and mental health problems]. Tijdschr Psychiatr 2019;61:773-8.

34 Lennox NG, Diggens JN, Ugoni AM. The general practice care of people with intellectual disability: barriers and solutions. J Intellect Disabil Res 1997;41(Pt 5):380-90.

35 Hametner B, Wassertheurer S, Kropf J, et al. Oscillometric estimation of aortic pulse wave velocity: comparison with intraaortic catheter measurements. Blood Press Monit 2013;18:173-6.

36 Benas D, Kornelakis M, Triantafyllidi $\mathrm{H}$, et al. Pulse wave analysis using the Mobil-O-Graph, Arteriograph and Complior device: a comparative study. Blood Press 2019;28:107-13.

37 Oppewal A, Hilgenkamp TIM. Is fatness or fitness key for survival in older adults with intellectual disabilities? J Appl Res Intellect Disabil 2020;33:1016-25

38 Hilgenkamp TIM, van Wijck R, Evenhuis HM. Feasibility and reliability of physical fitness tests in older adults with intellectual disability: a pilot study. J Intellect Dev Disabil 2012;37:158-62.

39 Hilgenkamp TIM, van Wijck R, Evenhuis HM. Feasibility of eight physical fitness tests in 1,050 older adults with intellectual disability: results of the healthy ageing with intellectual disabilities study. Intellect Dev Disabil 2013;51:33-47.

40 Craig CL, Marshall AL, Sjöström M, et al. International physical activity questionnaire: 12 -country reliability and validity. Med Sci Sports Exerc 2003;35:1381-95.

41 Rikli RE, Jones CJ. Senior fitness test manual.USA: Human Kinetics Publishers, 2001.

42 Bijen CBM, Runhaar J, Rijkels-Otters JBM, et al. Predictive value of early structural changes on radiographs and MRI for incident clinical and radiographic knee osteoarthritis in overweight and obese women. Semin Arthritis Rheum 2018;48:190-7.

43 Martel-Pelletier J, Barr AJ, Cicuttini FM, et al. Osteoarthritis. Nat Rev Dis Primers 2016;2:16072.

44 Cimolin V, Galli M, Grugni G, et al. Gait patterns in Prader-Willi and Down syndrome patients. J Neuroeng Rehabil 2010;7:28.

45 Boylan MR, Kapadia BH, Issa K, et al. Down syndrome increases the risk of short-term complications after total hip arthroplasty. $J$ Arthroplasty 2016;31:368-72.

46 Shaw ED, Beals RK. The hip joint in Down's syndrome. A study of its structure and associated disease. Clin Orthop Relat Res 1992;278:101-7.

47 Hresko MT, McCarthy JC, Goldberg MJ. Hip disease in adults with Down syndrome. J Bone Joint Surg Br 1993;75:604-7.

48 French ZP, Torres RV, Whitney DG. Elevated prevalence of osteoarthritis among adults with cerebral palsy. J Rehabil Med 2019:51:575-81. 
49 Altman R, Asch E, Bloch D, et al. Development of criteria for the classification and reporting of osteoarthritis: classification of osteoarthritis of the knee. Arthritis Rheumat 1986;29:1039-49.

50 de Knegt NC, Lobbezoo F, Schuengel C, et al. Self-Reported presence and experience of pain in adults with Down syndrome. Pain Med 2017;18:1247-63.

51 Peter WF, de Vet HCW, Terwee CB. Reliability of the animated activity questionnaire for assessing activity limitations of patients with hip and knee osteoarthritis. Musculoskeletal Care 2018;16:363-9.

52 Klässbo M, Larsson E, Mannevik E. Hip disability and osteoarthritis outcome score. An extension of the Western Ontario and McMaster universities osteoarthritis index. Scand J Rheumatol 2003;32:46-51.

53 de Groot IB, Reijman M, Terwee CB, et al. Validation of the Dutch version of the hip disability and osteoarthritis outcome score. Osteoarthritis Cartilage 2009;17:132.

54 Roos EM, Roos HP, Lohmander LS, et al. Knee Injury and Osteoarthritis Outcome Score (KOOS)--development of a selfadministered outcome measure. J Orthop Sports Phys Ther 1998;28:88-96.

55 Beekman AT, Deeg DJ, van Tilburg T, et al. Major and minor depression in later life: a study of prevalence and risk factors. $J$ Affect Disord 1995;36:65-75.

56 Beekman AT, Bremmer MA, Deeg DJ, et al. Anxiety disorders in later life: a report from the longitudinal aging study Amsterdam. Int $J$ Geriatr Psychiatry 1998;13:717-26.

57 Johnson EO, Roth T, Breslau N. The association of insomnia with anxiety disorders and depression: exploration of the direction of risk. J Psychiatr Res 2006;40:700-8.

58 van de Wouw E, Evenhuis HM, Echteld MA. Objective assessment of sleep and sleep problems in older adults with intellectual disabilities. Res Dev Disabil 2013;34:2291-303.

59 O'Dwyer C, McCallion P, Burke E, et al. Prevalence and associated factors of problem behaviours among older adults with intellectual disabilities in Ireland. Res Dev Disabil 2018;80:192-204.

60 Rojahn J, Aman MG, Matson JL, et al. The aberrant behavior checklist and the behavior problems inventory: convergent and divergent validity. Res Dev Disabil 2003;24:391-404.

61 Dettenborn L, Muhtz C, Skoluda N, et al. Introducing a novel method to assess cumulative steroid concentrations: increased hai cortisol concentrations over 6 months in medicated patients with depression. Stress 2012;15:348-53.

62 Khoury JE, Bosquet Enlow M, Plamondon A, et al. The association between adversity and hair cortisol levels in humans: a metaanalysis. Psychoneuroendocrinology 2019;103:104-17.

63 Steudte S, Stalder T, Dettenborn L, et al. Decreased hair cortisol concentrations in generalised anxiety disorder. Psychiatry Res 2011;186:310-4.

64 Gerritsen L, Staufenbiel SM, Penninx BWJH, et al. Longterm glucocorticoid levels measured in hair in patients with depressive and anxiety disorders. Psychoneuroendocrinology 2019:101:246-52

65 van de Wouw E, Evenhuis HM, Echteld MA. Comparison of two types of Actiwatch with polysomnography in older adults with intellectual disability: a pilot study. J Intellect Dev Disabil 2013;38:265-73.

66 Bastiaanse LP, Mergler S, Wielders J, et al. Observed vitamin D deficiency variations in older adults with intellectual disabilities, 2014. Available: https://www.semanticscholar.org/paper/ Nutrition\%2C-Nutritional-State-and-Related-ConditionsBastiaanse/f8f323978e80a9a85693d346d1d2ace66cfc3898 [Accessed 23 Dec 2020].

67 Sheppard JJ. Managing dysphagia in mentally retarded adults. Dysphagia 1991;6:83-7.

68 Bastiaanse LP, Hilgenkamp TIM, Echteld MA, et al. Prevalence and associated factors of sarcopenia in older adults with intellectual disabilities. Res Dev Disabil 2012;33:2004-12.

69 Bastiaanse LP, Mergler S, Evenhuis HM, et al. Bone quality in older adults with intellectual disabilities. Res Dev Disabil 2014:35:1927-33

70 Kruizenga HM, De Vet HCW, Van Marissing CME, et al. The SNAQ(RC), an easy traffic light system as a first step in the recognition of undernutrition in residential care. J Nutr Health Aging 2010;14:83-9.

71 Xue Q-L. The frailty syndrome: definition and natural history. Clin Geriatr Med 2011;27:1-15.

72 Clegg A, Young J, lliffe S, et al. Frailty in elderly people. Lancet 2013;381:752-62.

73 Schoufour JD, van Wijngaarden J, Mitnitski A, et al. Characteristics of the least frail adults with intellectual disabilities: a positive biology perspective. Res Dev Disabil 2014;35:127-36.
74 Fried LP, Tangen CM, Walston J, et al. Frailty in older adults: evidence for a phenotype. J Gerontol A Biol Sci Med Sci 2001;56:146-56.

75 Schoufour JD, Echteld MA, Evenhuis HM. Comparing two frailty measures in their ability to predict mortality among older people with intellectual disabilities, 2015. Available: https://www. semanticscholar.org/paper/Frailty-in-People-with-IntellectualDisabilities-\%3A-Schoufour/92dc61a6d6a9e183cfbb5764462d5f25 0e45ea77.j [Accessed 23 Dec 2020].

76 World Medical Association. WMA Declaration of Helsinki - Ethical principles for medical research involving human subjects. Fortaleza, Brazil: 64th WMA General Assembly, 2013.

77 College voor Zorgverzekeringen. Gebruikersgids verstandelijke beperking: algemene informatie, informatie per zorgzwaartepakket (ZZP) [User guide intellectual disability: general information, information per classification of levels of support, care and/ or treatment]., 2013. Available: https://docplayer.nl/4931768Gebruikersgids-verstandelijke-beperking-algemene-informatieinformatie-per-zorgzwaartepakket-zzp.html [Accessed 23 Dec 2020].

78 Durnin JVGA, Rahaman MM. The assessment of the amount of fat in the human body from measurements of skinfold thickness. 1967. Br J Nutr 2003:89:147-55.

79 Mathiowetz V, Volland G, Kashman N, et al. Adult norms for the box and block test of manual dexterity. Am J Occup Ther 1985;39:386-91.

80 Berg K. Measuring balance in the elderly: preliminary development of an instrument. Physiotherapy Canada 1989;41:304-11.

81 Dunn JM. Reliability of selected psychomotor measures with mentally retarded adult males. Percept Mot Skills 1978;46:295-301.

82 Berg K, Wood-Dauphinee S, Williams JI. The balance scale: reliability assessment with elderly residents and patients with an acute stroke. Scand J Rehabil Med 1995;27:27-36.

83 Singh SJ, Morgan MD, Scott S, et al. Development of a shuttle walking test of disability in patients with chronic airways obstruction. Thorax 1992;47:1019-24.

84 Singh SJ, Morgan MD, Hardman AE, et al. Comparison of oxygen uptake during a conventional treadmill test and the shuttle walking test in chronic airflow limitation. Eur Respir J 1994;7:2016-20.

85 Hui SS, Yuen PY. Validity of the modified back-saver sit-and-reach test: a comparison with other protocols. Med Sci Sports Exerc 2000;32:1655-9.

86 Hilgenkamp TIM, van Wijck R, Evenhuis HM. Physical fitness in older people with ID-Concept and measuring instruments: a review. Res Dev Disabil 2010;31:1027-38.

87 Hauser SL, Dawson DM, Lehrich JR, et al. Intensive immunosuppression in progressive multiple sclerosis. A randomized, three-arm study of high-dose intravenous cyclophosphamide, plasma exchange, and ACTH. N Engl J Med 1983;308:173-80

88 Palisano R, Rosenbaum P, Walter S, et al. Development and reliability of a system to classify gross motor function in children with cerebral palsy. Dev Med Child Neurol 1997;39:214-23.

89 Altman R, Alarcón G, Appelrouth D, et al. The American College of rheumatology criteria for the classification and reporting of osteoarthritis of the hip. Arthritis Rheum 1991;34:505-14.

90 Maricar N, Callaghan MJ, Parkes MJ, et al, Interobserver and intraobserver reliability of clinical assessments in knee osteoarthritis. J Rheumatol 2016;43:2171-8.

91 Smits-Engelsman B, Klerks M, Kirby A. Beighton score: a valid measure for generalized hypermobility in children. $J$ Pediatr 2011:158:119-23.

92 Tateuchi H. Gait- and postural-alignment-related prognostic factors for hip and knee osteoarthritis: toward the prevention of osteoarthritis progression. Phys Ther Res 2019;22:31-7.

93 van Herk R, van Dijk MA, Tibboel D, et al.. The Rotterdam elderly pain observation scale (REPOS): a new behavioral pain scale for non-communicative adults and cognitively impared elderly persons. $J$ Pain Manage 2008;1:367-78.

94 Rush AJ, Giles DE, Schlesser MA, et al. The inventory for depressive symptomatology (IDS): preliminary findings. Psychiatry Res 1986;18:65-87.

95 Mindham J, Espie CA. Glasgow anxiety scale for people with an intellectual disability (GAS-ID): development and psychometric properties of a new measure for use with people with mild intellectual disability. J Intellect Disabil Res 2003;47:22-30.

96 Zigmond AS, Snaith RP. The hospital anxiety and depression scale. Acta Psychiatr Scand 1983;67:361-70.

97 Hoekman J, Douma JCH, Kersten MCO, et al.. IDQOL - Intellectual Disability Quality of Life. NTZ: Nederlands tijdschrift voor zwakzinnigenzorg 2001;4:207-24. 
98 Moss S, Patel P, Prosser $\mathrm{H}$, et al. Psychiatric morbidity in older people with moderate and severe learning disability. I: development and reliability of the patient interview (PAS-ADD). Br J Psychiatry 1993; $163: 471-80$

99 Esbensen AJ, Rojahn J, Aman MG, et al. Reliability and validity of an assessment instrument for anxiety, depression, and mood among individuals with mental retardation. J Autism Dev Disord 2003;33:617-29.

100 Kraijer D, Plas J. Handboek Psychodiagnostiek en beperkte begaafdheid: Classificatie, test- en schaalgebruik. Amsterdam: Hartcourt Book Publisher, 2006.

101 Arrindel W, Ettema J. Handleiding bij Een multidimensionele psychopathologie indicator. Lisse: Swets \& Zeitlinger, 1986.

102 Evenhuis $\mathrm{H}$. Manual of the dementia questionnaire for persons with mental retardation (DMR). Amsterdam: Harcourt Assessment BV, 1995.
103 Wester VL, van Rossum EFC. Clinical applications of cortisol measurements in hair. Eur J Endocrinol 2015;173:M1-10.

104 Vellas B, Guigoz Y, Garry PJ, et al. The mini nutritional assessment (MNA) and its use in grading the nutritional state of elderly patients. Nutrition 1999;15:116-22.

105 Matson JL, Kuhn DE. Identifying feeding problems in mentally retarded persons: development and reliability of the screening tool of feeding problems (STEP). Res Dev Disabil 2001;22:165-72.

106 Mahoney FI, Barthel DW. Functional evaluation: the BARTHEL index. Md State Med J 1965;14:61-5.

107 Lawton MP, Brody EM. Assessment of older people: selfmaintaining and instrumental activities of daily living. Gerontologist 1969;9:179-86.

108 Kempen GI, Miedema I, Ormel J, et al. The assessment of disability with the Groningen activity restriction scale. conceptual framework and psychometric properties. Soc Sci Med 1996;43:1601-10. 